\title{
Association of Hard Ticks (Ixodidae) Infestation with Milk Production and Udder Health of Extensively Reared Dairy Goats
}

\author{
Sotiria Vouraki ${ }^{1, *(D)}$, Athanasios I. Gelasakis ${ }^{2}$ D, Vasiliki Papanikolopoulou ${ }^{1}$, Elias Papadopoulos ${ }^{3}(\mathbb{D}$ \\ and Georgios Arsenos ${ }^{1}$ (D)
}

check for updates

Citation: Vouraki, S.; Gelasakis, A.I.; Papanikolopoulou, V.; Papadopoulos, E.; Arsenos, G. Association of Hard Ticks (Ixodidae) Infestation with Milk Production and Udder Health of Extensively Reared Dairy Goats. Animals 2022, 12, 354. https:// doi.org/10.3390/ani12030354

Academic Editor: Jacek Wójtowski

Received: 31 December 2021

Accepted: 31 January 2022

Published: 1 February 2022

Publisher's Note: MDPI stays neutral with regard to jurisdictional claims in published maps and institutional affiliations.

Copyright: (C) 2022 by the authors. Licensee MDPI, Basel, Switzerland. This article is an open access article distributed under the terms and conditions of the Creative Commons Attribution (CC BY) license (https:// creativecommons.org/licenses/by/ $4.0 /)$.
1 Laboratory of Animal Husbandry, School of Veterinary Medicine, Faculty of Health Sciences, Aristotle University, 54124 Thessaloniki, Greece; vipapani@vet.auth.gr (V.P.); arsenosg@vet.auth.gr (G.A.)

2 Department of Animal Science, School of Animal Biosciences, Agricultural University of Athens, 11855 Athens, Greece; gelasakis@aua.gr

3 Laboratory of Parasitology and Parasitic Diseases, School of Veterinary Medicine, Faculty of Health Sciences, Aristotle University, 54124 Thessaloniki, Greece; eliaspap@vet.auth.gr

* Correspondence: svouraki@vet.auth.gr; Tel.: +30-2310999977

Simple Summary: Tick infestation and vector-mediated transmission of pathogens thereof challenge the production and health of extensively reared farm animals, causing substantial economic losses and poor welfare. Adverse effects of tick infestation have been documented in cows and sheep. However, relevant studies in goats are scarce. To address this dearth of knowledge, we investigated the association between hard tick infestation, milk production and udder health traits of extensively reared dairy goats in Greece. Tick infestation was significantly associated with impaired udder health, but not with milk yield and quality. Evidence-based tick mitigation strategies in goats are necessary to enhance animal health status and reduce the risk of public health issues deriving from tick-borne pathogen infections.

\begin{abstract}
Extensively reared ruminants are seasonally exposed to ticks. Tick-related production losses and health issues have been well documented in cows and sheep but not in goats where relevant literature is scarce. The objective here was to investigate the association of hard tick infestation with milk production and udder health of dairy goats reared extensively. A cross-sectional study was carried out during May and June, in two dairy goat farms. The farms were located in Central and Northern Greece and were representative of typical extensive production systems. A total of 304 goats ( $n=152$ from each farm) were randomly selected. Each goat was examined for presence of hard ticks. Daily milk yield and quality characteristics were recorded. Udder health status was determined by milk somatic cell count (SCC) and total viable count (TVC). Tick infestation prevalence was $28.6 \%$; it was associated with a significant $(p<0.001)$ increase in SCC and TVC $(84.0 \%$ and $78.6 \%$, respectively). The latter meant that infested goats were 3.7 times more prone to udder health problems $(p<0.001)$. There were not any significant effects $(p>0.05)$ on milk production. Overall, results suggest that control of tick infestation in extensively reared dairy goat herds is important for enhancing health and welfare status.
\end{abstract}

Keywords: tick infestation; dairy goats; extensive farming system; milk production; udder health

\section{Introduction}

Ticks are blood-feeding ectoparasites of vertebrate animals. Warm and humid climates favour their survival and activity, and infected pastures facilitate their transmission. As a result, extensively reared ruminants in regions with such climatic conditions are periodically or even permanently challenged by hard tick infestation [1,2]. This pattern is being modified 
following climate change, a situation which is expected to intensify the problem and broaden the geographical distribution of hard ticks in the future [3,4].

In cattle and sheep farms, tick infestation has been linked to severe monetary losses. For example, an average cost of approximately USD 7.3/animal/year has been estimated in tick-infested dairy cattle [5]. Monetary losses result from indirect (tick-borne diseases) and direct (distress) effects of tick infestation on animal production and health [1,6]. In cattle, tick infestation has been associated with impaired growth, udder health and skin lesions and with reduced milk production [7-13]. Moreover, in sheep, negative associations with live weight gain, wool production and blood biomarkers (packed cell volume, haemoglobin, and total antioxidant capacity) have been reported $[6,14,15]$.

In extensively reared goats, tick infestation is identified as a major epidemiological issue, especially in tropical and subtropical regions [16]. A high diversity of hard tick species infesting goats has been reported in Middle East and North Africa [17] and a prevalence of circa (ca.) $85 \%$ found in South Africa [18]. Tick infestation has also been reported in high prevalence in South Asia (ca. 87\% and 78-100\% in Pakistan and India, respectively $[16,19,20])$. Moreover, it has been estimated as moderate to high in Eastern Europe (ca. 30\% in Southern Greece and 100\% in Romania, respectively [21,22]). The impact of tick infestation on goat performance has been accessed in relation to tick-borne diseases such as anaplasmosis, babesiosis and theileriosis [6,23]. Anaplasmosis, caused by Anaplasma phagocytophilum, has been found to severely reduce milk yield [23]. The estimated tick-borne disease-related monetary losses in China approximate to USD 2 per goat [24]. However, the direct association between tick infestation and economically important production and health traits remains unknown.

In Greece, dairy goat farming is a significant agricultural activity, with the national herd being the largest in the European Union (ca. 3.6 million [25]). This population is mainly composed of indigenous breeds, namely Eghoria and Skopelos, and reared in extensive farming systems, where goats cover their nutritional demands mostly by exploiting natural pasturelands [26]. In these systems, infestation of goats with ticks mainly of the genus Rhipichephalus is commonly observed during the warm months of the year (from May to August) [27-30], and is expected to escalate in the light of climate change, possibly leading to production losses and health issues. Although chemical control of tick infestation with zero withdrawal time in milk is available [31,32], it is presumed by farmers as a rather costly practice. Moreover, prevention measures, such as rotational grazing and avoiding common pastures shared with other farmers, are rarely implemented. Estimating the possible negative association between tick infestation and goat performance as well as health status could justify the adoption of control and prevention strategies by farmers for improved animal welfare and economically sustainable dairy goat farming.

Therefore, the objective of our study was to investigate the association of hard tick infestation with milk production, and udder health of dairy goats reared under extensive farming systems in Greece.

\section{Materials and Methods}

\subsection{Herds and Animals}

A cross-sectional study was carried out within the framework of Sustainable Organic and Low Input Dairying project (SOLID; 2011-2015) in two representative dairy goat farms with a reported problem of tick infestation, in Central (island of Alonnisos, Farm A) and Northern Greece (Thessaloniki, Farm B, Figure 1) in May and June, respectively. The principal characteristics of the two farms are presented in Table 1. In these farms, a typical grazing scheme throughout the year for traditional goat farming was practiced as described by Gelasakis et al. [19]. In May, the average temperature and humidity in the island of Alonnisos were $20^{\circ} \mathrm{C}$ and $68 \%$, respectively, whereas in June the respective values for the area of Thessaloniki were $22{ }^{\circ} \mathrm{C}$ and $60 \%$ (historical data available at World Weather Online, www.worldweatheronline.com; accessed on 30 December 2021). 


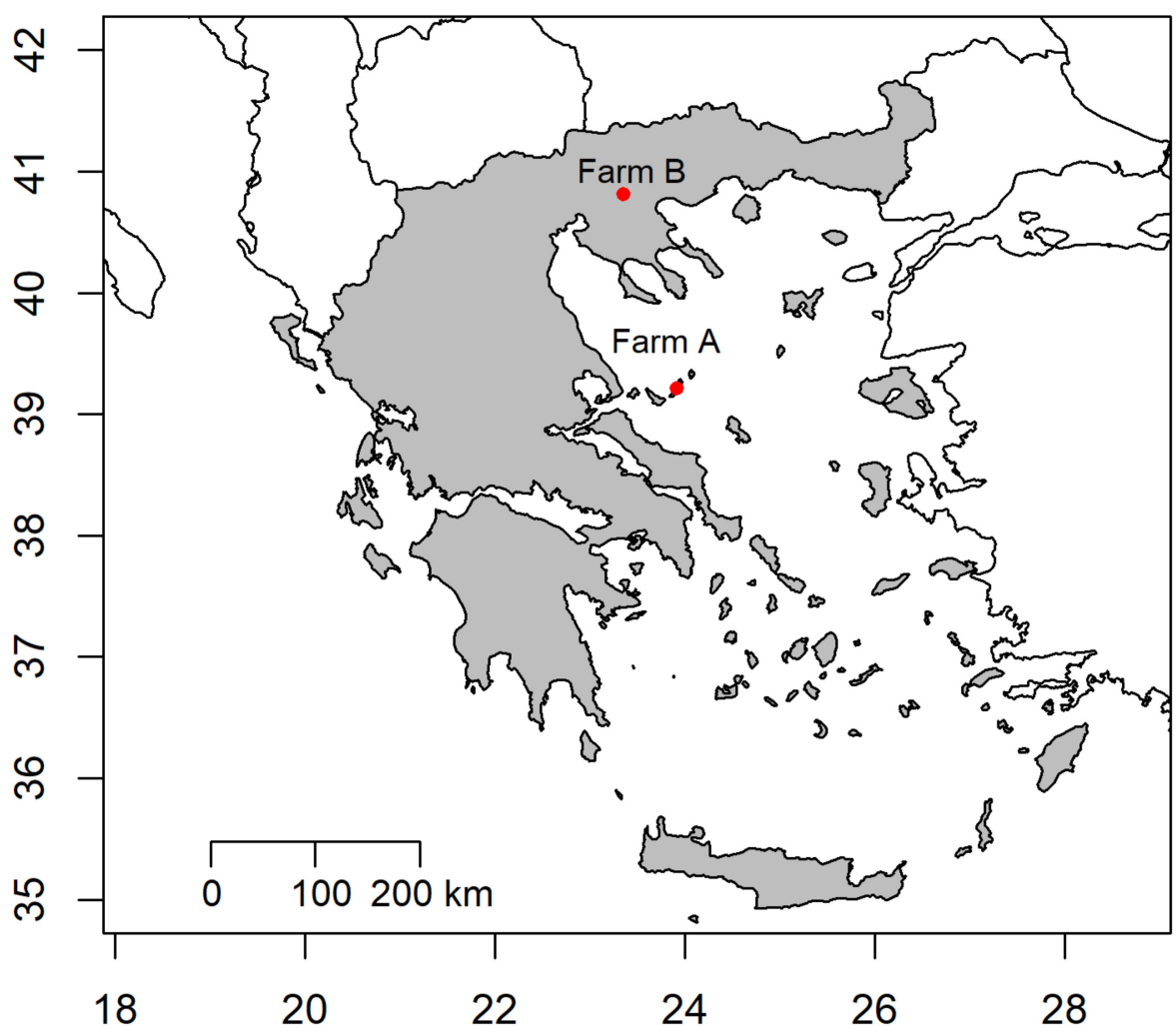

Figure 1. Map of Greece illustrating the regions in which the two studied farms (Farm A and B) were located.

Table 1. Principal characteristics of the two goat farms that participated in the study.

\begin{tabular}{ccc}
\hline Characteristic & Farm A & Farm B \\
\hline Breed & Skopelos & Eghoria \\
Number of adult goats & 250 & 1200 \\
Number of bucks & 20 & 85 \\
Number of yearlings & 70 & 215 \\
Goat replacement rate (\%) & 15 & 15 \\
Buck replacement rate (\%) & 25 & 30 \\
Age of yearlings at first & 9 & 7 \\
mating (months) & & 180 \\
Milk production & 280 & November \\
(kg/goat/lactation period) & December & ivermectin \\
Kidding season & ivermectin & 9 \\
Ectoparasitic treatment & 7 & June \\
Last ectoparasitic treatment & May & 6 \\
(months ago) & 10 & grassland/shrubland/woodland \\
Sampling month & grassland/shrubland/woodland
\end{tabular}

A total of 304 adult goats ( $n=152$ in each of the two farms) were randomly selected for the study. Selected goats belonged to two indigenous Greek breeds (Skopelos and Eghoria in Farms A and B, respectively, Table 1).

\subsection{Data Collection}

Animal sampling corresponded to the 5th and 7th month of lactation in Farms A and B, respectively. Prior to milking, all studied goats were thoroughly examined by the same veterinarian for the presence of hard ticks; tick infestation was confirmed when at least 10 ticks were detected. This threshold was defined based on authors' experience and according to the mean tick infestation severity reported in a previous epidemiological study 
in Greece [33]. All ticks were carefully removed from the skin of a representative sample of infested goats $(20 \%, n=18)$ using a pair of forceps and put into a numbered vial containing ethanol $70 \%$. A total of 324 ticks were collected.

Subsequently, a milk sample was collected aseptically from both udder halves in order to be tested for total viable count (TVC, Bactoscan FC). Afterwards, each goat was handmilked in an individual bucket and the produced milk was weighed. Finally, a milk sample was collected from the milking bucket and used for chemical analyses, which included fat, protein, lactose, and solids-non-fat (SNF) content (MilkoScan FT+) and for somatic cell count (SCC) assessment (Fossomatic FC). Sampling, handling, and analysis of milk samples have been described in detail in previous studies [34,35].

\subsection{Data Handling}

The official A4 method described by the International Committee of Animal Recording [36] was used to estimate daily milk yield. Based on daily milk yield and records of its composition, fat, protein, lactose, and SNF yields were also estimated. Records of SCC and TVC were used to evaluate goat udder health status; goats producing milk with SCC $>10^{6}$ cells $/ \mathrm{mL}$ and TVC $>2 \times 10^{4} \mathrm{cfu} / \mathrm{mL}$ were considered as having impaired udder health status. After quality control, a total of 274,214 and 303 records of milk composition, SCC and TVC, respectively were considered to be valid for further statistical analysis. The final dataset used for the analysis is available in Dataset $\mathrm{S} 1$.

\subsection{Statistical Analysis}

Prevalence of tick infestation and descriptive statistics of all studied traits for tick infested and non-infested goats were calculated within and across farms. Prior to statistical analyses, milk production traits as well as SCC and TVC were logarithmically transformed (natural $\log$ ) to ensure normality of distribution. Moreover, exploratory data analysis was performed with visual observation of box and whisker plots and count plots (Supplement Figures S1 and S2). Preliminary analyses were performed to identify explanatory variables for all studied traits; the fixed effects of tick infestation, farm and goat age were tested using the forward selection method. Models were tested and compared for goodness of fit using adjusted coefficient of determination, residual standard error, Akaike's information criterion and Bayesian information criterion; residuals vs. fitted were also plotted (Supplement Table S1 and Figure S3).

According to preliminary analyses, the effect of tick infestation on daily milk, fat, protein, lactose, and SNF yield and milk SCC and TVC was estimated using the following linear model:

$$
\mathrm{Y}_{\mathrm{ij}}=\mu+\mathrm{T}_{\mathrm{i}}+\mathrm{F}_{\mathrm{j}}+\mathrm{e}_{\mathrm{ij}}
$$

where: $Y_{i j}$ is the dependent variable; $\mu$ is the overall population mean; $T_{i}$ is the fixed effect of tick infestation ( $\mathrm{i}=2$ levels; $0=$ no tick infestation, $1=$ tick infestation); $F_{j}$ is the fixed effect of the farm ( $j=2$ levels; $1=$ Farm A, $2=$ Farm B); $e_{i j}$ is the residual error.

The effect of tick infestation on udder health status (binary trait) was analysed with a non-linear model, which included the same effects as model (1) and a logit function for binomial distribution.

Given that breeds and lactation stage were confounded within farms, only the fixed effect of farm was included in the above analyses. All analyses were conducted using $\mathrm{R}$ statistical package "stats" [37] and the level of statistical significance was set at $p=0.05$.

\section{Results}

\subsection{Descriptive Statistics}

The collected ticks were morphologically identified using standard morphological identification keys [38]. The main (90\%,292/324 ticks) species was Rhipicephalus sanguineus, while other minor species $(10 \%, 32 / 324$ ticks) were also detected (Dermacentor marginatus, Ixodes gibbosus, Rhipicephalus bursa, and Ixodes ricinus). Prevalence of tick infestation is presented in Figure 2. Across farms, a prevalence of 28.6\% (87/304 goats) was found. 
Between farms, the highest prevalence was reported in Farm B (36.2\% vs. 21.1\% in Farm A).

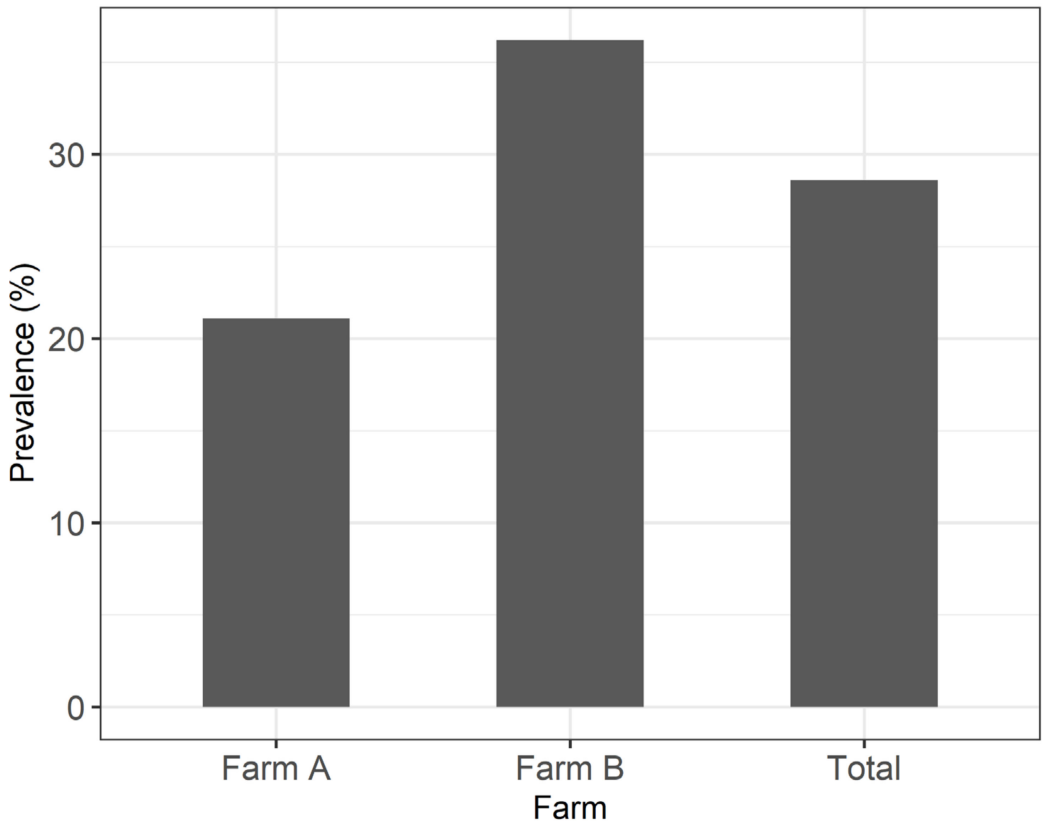

Figure 2. Tick infestation prevalence (\%) in the studied farms.

Descriptive statistics of all continuous studied goat traits and prevalence of impaired udder health status for tick-infested and non-infested goats are presented in Table 2 and Figure 3, respectively. Across farms, the average daily milk yield and milk components were lower in infested compared to non-infested goats, whereas milk SCC and TVC were higher (Table 1). Moreover, a higher prevalence of impaired udder health status was found in infested goats $(48.4 \%, 31 / 64$ goats) compared to non-infested ones (18.8\%, 28/149 goats).

Table 2. Descriptive statistics for goat traits studied in Farms A and B for tick-infested, non-infested and all (total) studied goats.

\begin{tabular}{|c|c|c|c|c|c|c|c|}
\hline \multirow[b]{2}{*}{ Trait } & \multirow[b]{2}{*}{ Goats } & \multicolumn{2}{|c|}{ Farm A } & \multicolumn{2}{|r|}{ Farm B } & \multicolumn{2}{|r|}{ Total } \\
\hline & & $N$ & Mean $\left( \pm S D^{1}\right)$ & $N$ & Mean $\left( \pm S^{1}\right)$ & $N$ & Mean $\left( \pm S D^{1}\right)$ \\
\hline \multirow[t]{3}{*}{ Daily milk yield (g) } & Tick-infested & 32 & $1156.7(419.82)$ & 55 & $659.0(173.61)$ & 87 & $842.1(375.14)$ \\
\hline & Non-infested & 120 & $1063.2(348.81)$ & 97 & $742.0(186.53)$ & 217 & $919.6(328.81)$ \\
\hline & Total & 152 & $1082.9(365.42)$ & 152 & $712.0(185.74)$ & 304 & 897.4 (343.87) \\
\hline \multirow[t]{3}{*}{ Daily fat yield (g) } & Tick-infested & 26 & $57.1(17.95)$ & 52 & $31.6(8.54)$ & 78 & $40.1(17.30)$ \\
\hline & Non-infested & 99 & $55.2(15.53)$ & 97 & $35.0(8.75)$ & 196 & $45.2(16.18)$ \\
\hline & Total & 125 & $55.6(16.01)$ & 149 & $33.8(8.80)$ & 274 & $43.8(16.63)$ \\
\hline \multirow[t]{3}{*}{ Daily protein yield (g) } & Tick-infested & 26 & $44.6(14.82)$ & 52 & $24.4(5.84)$ & 78 & $31.2(13.62)$ \\
\hline & Non-infested & 99 & $39.7(10.89)$ & 97 & $26.1(6.46)$ & 196 & $33.0(11.26)$ \\
\hline & Total & 125 & 40.7 (11.92) & 149 & $25.5(6.28)$ & 274 & $32.5(11.98)$ \\
\hline \multirow[t]{3}{*}{ Daily lactose yield (g) } & Tick-infested & 26 & $49.4(20.52)$ & 52 & $28.2(7.18)$ & 78 & $35.3(16.48)$ \\
\hline & Non-infested & 99 & $43.9(13.89)$ & 97 & $31.4(7.96)$ & 196 & 37.7 (12.93) \\
\hline & Total & 125 & $45.0(15.57)$ & 149 & $30.3(7.82)$ & 274 & $37.0(14.04)$ \\
\hline \multirow[t]{3}{*}{ Daily SNF ${ }^{2}$ yield (g) } & Tick-infested & 26 & $104.7(39.22)$ & 52 & $58.7(14.01)$ & 78 & $74.0(33.23)$ \\
\hline & Non-infested & 99 & $93.2(27.47)$ & 97 & $64.2(15.83)$ & 196 & $78.8(26.72)$ \\
\hline & Total & 125 & $95.6(30.47)$ & 149 & $62.3(15.40)$ & 274 & $77.5(28.74)$ \\
\hline \multirow[t]{3}{*}{ Milk SCC ${ }^{3}\left(\times 10^{3}\right.$ cells $\left./ \mathrm{mL}\right)$} & Tick-infested & 13 & $1455.1(2052.42)$ & 52 & $3238.8(3736.53)$ & 65 & $2882.0(3525.98)$ \\
\hline & Non-infested & 53 & $1723.4(3940.92)$ & 96 & $1377.8(1693.78)$ & 149 & $1500.7(2706.63)$ \\
\hline & Total & 66 & $1670.6(3635.10)$ & 148 & $2031.7(2737.25)$ & 214 & $1920.3(3038.30)$ \\
\hline \multirow[t]{3}{*}{ Milk TVC ${ }^{4}\left(\times 10^{3} \mathrm{cfu} / \mathrm{mL}\right)$} & Tick-infested & 32 & $10.2(8.17)$ & 54 & 323.9 (581.77) & 86 & $207.2(484.09)$ \\
\hline & Non-infested & 120 & $53.1(265.77)$ & 97 & $87.7(251.11)$ & 217 & $68.6(259.30)$ \\
\hline & Total & 152 & $44.1(236.62)$ & 151 & $172.2(415.75)$ & 303 & $107.9(343.46)$ \\
\hline
\end{tabular}

${ }^{1} \mathrm{SD}=$ standard deviation ${ }^{2} \mathrm{SNF}=$ solids-non-fat ${ }^{3} \mathrm{SCC}=$ somatic cell count ${ }^{4} \mathrm{TVC}=$ total viable count. 


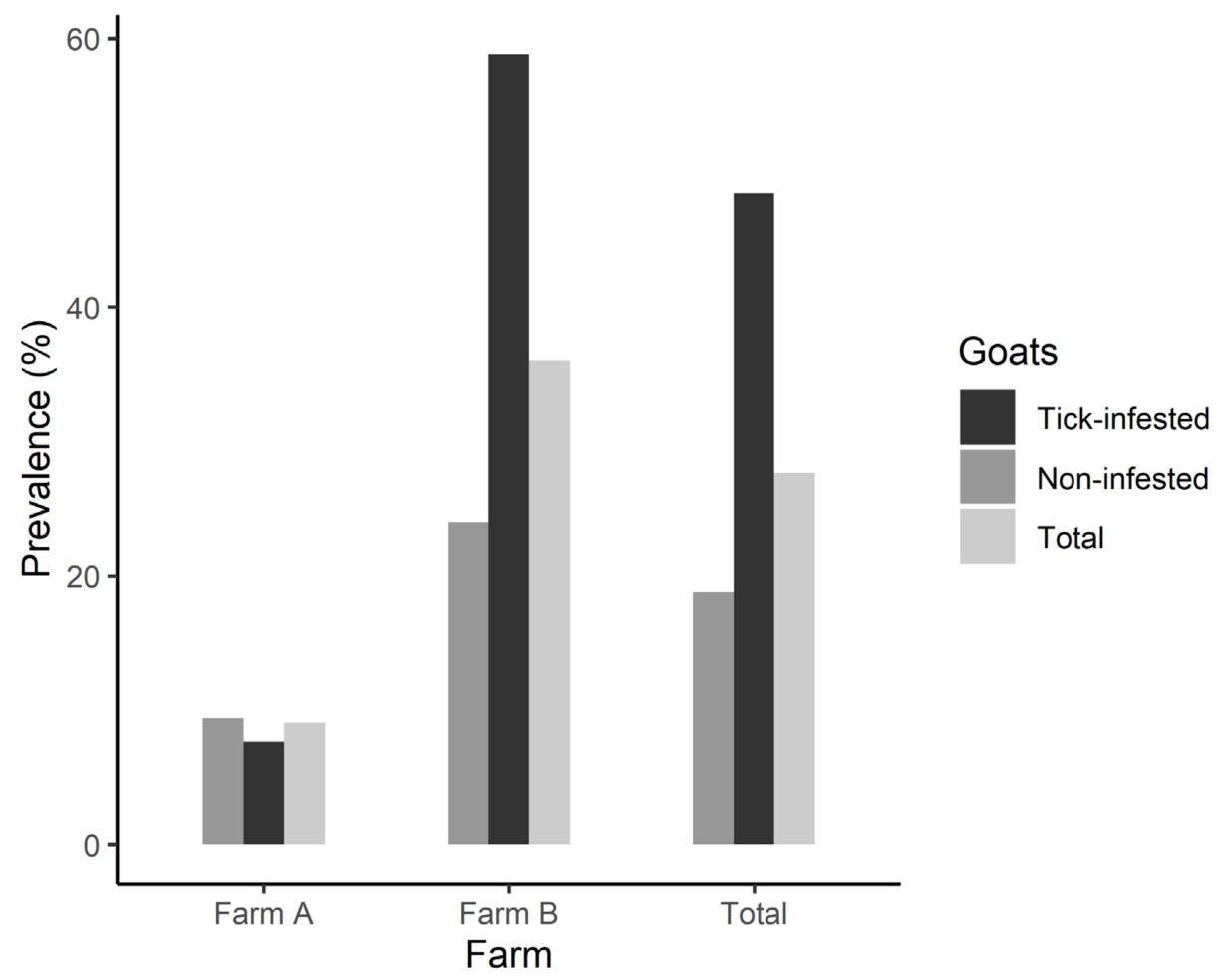

Figure 3. Impaired udder health status prevalence in the studied farms for tick-infested, non-infested and all (total) studied goats.

\subsection{Effect of Tick Infestation on Goat Productivity and Udder Health}

The effects of tick infestation on milk production and udder health traits are presented in Table 3; significant effects $(p<0.01)$ were found on udder health traits. Specifically, tick infestation resulted in an increase in SCC by $84.0 \%( \pm 19.72 \%, p<0.001)$ and TVC by $78.6 \%$ $( \pm 17.59 \%, p<0.001)$. Moreover, infested goats were 3.65 times more likely to have impaired udder health status $(p<0.001)$ compared to non-infested ones. No significant effects were reported on milk production traits $(p>0.05)$.

Table 3. Effects ( $\beta$-coefficients, standard errors) of tick infestation on milk production and udder health traits.

\begin{tabular}{cccc}
\hline Trait & $\beta$-Coefficient & SE $^{\mathbf{1}}$ & $p$-Value \\
\hline Daily milk yield $(\mathrm{g}, \mathrm{ln})$ & -0.04 & 0.040 & 0.333 \\
Daily fat yield $(\mathrm{g}, \mathrm{ln})$ & -0.06 & 0.039 & 0.136 \\
Daily protein yield $(\mathrm{g}, \mathrm{ln})$ & 0.00 & 0.037 & 0.984 \\
Daily lactose yield $(\mathrm{g}, \mathrm{ln})_{\text {Daily SNF }^{2} \text { yield }(\mathrm{g}, \mathrm{ln})}$ & -0.03 & 0.042 & 0.433 \\
Milk SCC $^{3}(\mathrm{cells} / \mathrm{mL}, \mathrm{ln})$ & -0.02 & 0.039 & 0.659 \\
Milk TVC $^{4}(\mathrm{cfu} / \mathrm{mL}, \mathrm{ln})$ & 0.61 & 0.176 & $<0.001$ \\
Udder health status $($ odds ratio) & 0.58 & 0.162 & $<0.001$ \\
\hline
\end{tabular}

${ }^{1} \mathrm{SE}=$ standard error ${ }^{2} \mathrm{SNF}=$ solids-non-fat ${ }^{3} \mathrm{SCC}=$ somatic cell count ${ }^{4} \mathrm{TVC}=$ total viable count.

\section{Discussion}

To the best of our knowledge this is the first study of the possible association of tick infestation with milk production and udder health traits of dairy goats reared in extensive farming systems. Tick infestation was associated with impaired udder health status, but not with milk yield and quality.

In cattle, the impact of tick infestation on animal performance has been mostly investigated under experimental conditions involving artificial infestations [8-10,39]. This allows for a true control group avoiding possible confounding effects. However, it could lead 
to overestimations compared to the situation on field [11]. In our study, this impact was investigated in extensively reared goats under natural tick infestation conditions in order to reveal possible associations that could be attributable to tick-infestation during the ticks' highest activity season. Previous studies have shown that ticks of the genus Rhipicephalus, which are the most prevalent hard ticks in goat herds in Greece (ca. 90\%, [30]), are more active during the warm period of the year and especially from May to July/August [27,28]. For this reason, in our study, sampling was performed within this period and specifically, in May and June for Farms A and B, respectively; this decision was also supported by past observations of farmers who reported a systematic tick infestation problem during these months.

The reported tick infestation prevalence in the studied farms was ca. $29 \%$ and in agreement with the one reported by Dimanopoulou et al. [21] in areas of Southern Greece (ca. 30\%). However, it was lower compared to the estimates in Romania, South Asia, and South Africa (ca. 85-100\% [16,18-20,22]). Between the two studied farms, the prevalence was relatively higher in Farm B located in the area of Thessaloniki (Northern Greece). Given that the climatic conditions (temperature and humidity) in the two studied areas were similar at the time of tick infestation assessment (historical data available at World Weather Online, www.worldweatheronline.com; accessed on 30 December 2021), this difference might be associated with diverse vegetation patterns, livestock stocking rate, and soil microclimate (soil surface temperature and relative humidity, [4]) and/or with different host resistance levels.

The impact of tick infestation on milk production has been widely studied in dairy cows. In Australia and Africa, infestation with ticks of the genus Rhipicephalus spp. was found to result in significant loss of daily milk yield (ca. $9 \mathrm{~mL}$ loss per engorged tick) in Holstein-Friesian and Sanga cattle, respectively $[8,10]$. Moreover, in Brazil, tick infestation was associated with a significant reduction in the total lactation milk yield of Holstein $\times$ Zebu cows (ca. 90 litres/cow, [13]). Such findings have been attributed to the loss of appetite resulting in reduced feed intake and, consequently, energy loss ([10]. However, no significant associations were reported in the studies of Norval et al. [9,39] for dairy cattle infested with Rhipicephalus spp. and Amblyomma spp. ticks. The latter findings are in accordance with those of the present study for dairy goats, where the association with daily milk yield was negative but not statistically significant. Moreover, no other significant effects on milk components (fat, protein, lactose and SNF) yield were found, which is supported by the findings of Jonsson et al. [10] regarding fat and protein yield, and content in the milk of tick-infested goats.

According to research in cattle, tick infestation severity could be a source of variation dictating the significance of effects on productivity $[10,11]$. In our study, such an investigation was not performed since counting of the total number of ticks engorged in each animal was not feasible and would cause unnecessary distress in the animals. Moreover, the number of ticks infesting an animal is a dynamic situation not easily described under a cross-sectional epidemiological study-design. In a previous epidemiological study in Greece, tick infestation severity in May and June ranged from 1 to 21 engorged ticks per goat [33]. Given this variability, it could be speculated that significant adverse effects might occur in cases of severe tick infestation. This is further supported by the fact that, although not statistically significant, a decrease in all studied milk production traits was reported in infested compared to non-infested goats. Therefore, the effect on goat productivity should be further studied after quantifying infestation to account it as an infestation severity index; in any case, a prospective study-design is warranted.

Significant effects of tick infestation were found on udder health; infested goats had increased milk SCC and TVC (ca. 80\% increase, in each case) and were more likely (ca. 4 times) to have impaired udder health status. In dairy cows, Jonsson et al. [10] found no significant effect of tick infestation on milk SCC. However, in other studies [9,12], a significant adverse association with SCC as well as the incidence of mastitis has been reported, in consistence with the results of our study. Such an adverse effect on udder health could 
be possibly explained by an overall immunosuppressive impact of tick infestation and/or increased oxidative stress. Iqbal et al. [40] reported a significant reduction in the number of lymphocytes in goats infested with ectoparasites including ticks. Moreover, in cows, tick infestation has been shown to reduce the percentage of $\mathrm{T}$ lymphocytes and, in a lesser extent, B lymphocytes and the antibody response to specific protein antigens [7] reaffirming immunosuppression potential. Furthermore, in tick-infested sheep, an increase of serum total antioxidant capacity has been reported, which is likely to predispose to several health disorders [15]. Further relevant research in goats could help towards understanding the underlying mechanisms and sufficiently elucidate the adverse association between tick infestation and goat udder health status.

In the present study, tick infestation was defined by taking into account ticks attached to any part of the body. However, the reported adverse association with goat udder health status could have also resulted from the inflammation and transmission of mastitis-related pathogens from ticks specifically attached to the udder. In the study of Moges et al. [12], the presence of ticks and/or lesions on the udder of dairy cows was found to be a risk factor of mastitis. Staphylococcus aureus, the most common pathogen among coagulase-positive staphylococci leading to clinical and subclinical mastitis [41], has been isolated from ticks of the genus Rhipichephalus spp. that infested sheep and cattle in Iraq and Texas [42,43]. Moreover, in the study of Andreotti et al. [43], coagulase-negative staphylococci and Streptococcus spp. have also been isolated from ticks of the same genus. In addition, a variety of Gram-negative bacteria, including Escherichia coli, Salmonella spp., Klebsiella spp., Serratia spp., and Enterobacter spp., have been isolated from Rhipichephalus spp. ticks in Turkey and Iraq $[42,44]$. All the above bacteria have been also isolated from the milk of extensively reared dairy goats with subclinical mastitis in Greece [33]. Future studies investigating microbiological cultures from the milk of dairy goats infested with ticks attached to the udder skin could help to identify tick-borne bacterial pathogens and verify their association with udder health; valuable information could also be provided by studying the tick microbiome.

In our study, goats were considered to have impaired udder health status when producing milk with SCC $>10^{6}$ cells $/ \mathrm{mL}$ and TVC $>2 \times 10^{4} \mathrm{cfu} / \mathrm{mL}$. In the study of Gelasakis et al. [34], 78\% of goat milk samples with SCC and TVC above these limits were found to have positive microbiological cultures, therefore suggesting a strong association with subclinical mastitis. Subclinical mastitis is known to cause major financial losses for small ruminant farmers due to increased treatment and replacement costs and adverse effects on milk production [45,46]. Specifically, in extensive dairy goat herds in Greece, subclinical mastitis has been associated with reduced daily milk yield (by $5.7 \%$ ) as well as fat and lactose yield $[34,35]$. Therefore, although no direct effects of tick infestation on milk production were reported in our study, indirect effects and, hence, economic losses due to impaired goat udder health status could be assumed.

Based on our findings and previous knowledge on production losses, mortality rates, and veterinary treatment costs associated with tick-borne diseases $[15,23,24]$, tick infestation could be considered an issue of substantial economic importance for extensive goat farming systems. This importance may be even greater in the near future given that climate change is expected to impact the population and transmission dynamics, seasonal activity, and abundance of ticks $[3,4,47]$. In this regard, prevention and control measures against tick infestation could help towards increasing the economic sustainability of the sector and the health and welfare status of the animals. In addition to health and welfare-related issues underpinning the necessity of tick mitigation strategies, further research taking into account tick infestation severity could further help to increase their adoption by estimating an economic threshold above which chemical control of tick infestation would be costeffective [11]. Moreover, adoption of tick control measures is expected to be beneficial towards a one health perspective considering that ticks are vectors of many zoonoses [48]. 


\section{Conclusions}

According to the present study, tick infestation significantly contributes to udder health problems, though it does not seem to affect milk production of dairy goats reared in extensive farming systems in Greece. Adoption of prevention and available control measures to reduce tick infestation prevalence in dairy goat herds is expected to improve goats' udder health status and, hence, be also beneficial in terms of production and financial sustainability. Further research taking into account tick infestation severity is recommended for assessing potential adverse effects on goat productivity and for establishing an economic threshold for tick infestation control.

Supplementary Materials: The following are available online at https:/ /www.mdpi.com/article/ 10.3390/ani12030354/s1, Dataset S1: Total dataset of goat traits used for the analyses. Figure S1: Distribution of goat age in the studied Farms A and B (count plot); Figure S2: Relationship (A-G: box and whisker plots and $\mathrm{H}$ : count plot) of milk production and udder health traits with tick infestation; Figure S3: Residuals vs fitted plots for linear models used to analyse the association of tick infestation with milk production and udder health traits $(\mathrm{SNF}=$ solids-non-fat; $\mathrm{SCC}=$ somatic cell count; TVC = total viable count); Table S1: Comparison of goodness of fit of linear and non-linear models tested for estimating the effect of tick infestation on milk production and udder health goat traits.

Author Contributions: Conceptualisation, S.V., A.I.G., V.P., E.P. and G.A.; methodology, S.V., A.I.G., E.P. and G.A.; validation, S.V.; formal analysis, S.V.; investigation, A.I.G., E.P. and G.A.; resources, A.I.G., E.P. and G.A.; data curation, S.V. and A.I.G.; writing—original draft preparation, S.V.; writingreview and editing, S.V., A.I.G., V.P., E.P. and G.A.; visualisation, S.V.; supervision, A.I.G., E.P. and G.A.; project administration, A.I.G., E.P. and G.A.; funding acquisition, G.A. All authors have read and agreed to the published version of the manuscript.

Funding: This research was funded by the European Commission Seventh Framework Programme (FP7 Food, Agriculture and Fisheries, Biotechnology) for the project Sustainable Organic and Low Input Dairying (SOLID), grant number FP7-KBBE-266367.

Institutional Review Board Statement: The study was conducted according to the guidelines of the Declaration of Helsinki, and approved by the Research Committee of the Aristotle University of Thessaloniki (26362/03.05.2011) within the framework of SOLID project.

Informed Consent Statement: Not applicable.

Data Availability Statement: Data presented in this study is contained within the article and Supplementary Materials (Dataset S1 and Supplement 1).

Conflicts of Interest: The authors declare no conflict of interest. The funders had no role in the design of the study; in the collection, analyses, or interpretation of data; in the writing of the manuscript, or in the decision to publish the results.

\section{References}

1. Eskezia, B.G.; Desta, A.H. Review on the impact of ticks on livestock health and productivity. J. Biol. Agric. Healthc. 2016, 6, 1-7.

2. Gelasakis, A.I.; Valergakis, G.E.; Arsenos, G. Health and welfare of indigenous goat breeds from dairy farms in Greece. In Sustainable Goat Production in Adverse Environments: Volume I; Simões, J., Gutiérrez, C., Eds.; Springer: Cham, Switzerland, 2017; pp. 223-246. [CrossRef]

3. Estrada-Peña, A.; Venzal, J.M. Climate niches of tick species in the Mediterranean region: Modelling of occurrence data, distributional constraints, and impact of climate change. J. Med. Entomol. 2006, 44, 1130-1138. [CrossRef]

4. Estrada-Peña, A. Tick-borne pathogens, transmission rates and climate change. Front. Biosci. 2009, 14, 2674-2687. [CrossRef] [PubMed]

5. Food and Agriculture Organisation. Module 1. Ticks: Acaricide Resistance: Diagnosis, Management and Prevention. In Guidelines Resistance Management and Integrated Parasite Control in Ruminants; FAO: Rome, Italy, 2004; pp. 25-77. Available online: http://www.fao.org/tempref/docrep/fao/010/ag014e/ag014e05.pdf (accessed on 30 April 2020).

6. Hurtado, O.J.B.; Giraldo-Ríos, C. Economic and health impact of the ticks in production animals. In Ticks and Tick-Borne Pathogens; Abubakar, M., Perera, P.K., Eds.; IntechOpen: London, UK, 2018; pp. 1-19. [CrossRef]

7. Inokuma, H.; Kerlin, R.L.; Kemp, D.H.; Willadsen, P. Effects of cattle tick (Boophilus microplus) infestation on the bovine immune system. Vet. Parasitol. 1993, 47, 107-118. [CrossRef] 
8. Norval, R.A.I.; Sutherst, R.W.; Kurki, J.; Kerr, J.D.; Gibson, J.D. The effects of the brown-ear tick, Rhipicephalus appendiculatus, on milk production of Sanga cattle. Med. Vet. Entomol. 1997, 11, 148-154. [CrossRef] [PubMed]

9. Norval, R.A.I.; Sutherst, R.W.; Gibson, J.D.; Kerr, J.D.; Thorne, L.M.; Ellenhauge, A. The effects of the brown-ear tick, Rhipicephalus appendiculatus, on milk production in dairy cattle. Med. Vet. Entomol. 1997, 11, 155-158. [CrossRef]

10. Jonsson, N.N.; Mayer, D.G.; Matschoss, A.L.; Green, P.E.; Ansell, J. Production effects of cattle tick (Boophilus microplus) infestation on high yielding dairy cows. Vet. Parasitol. 1998, 78, 65-77. [CrossRef]

11. Jonsson, N.N. The productivity effects of cattle tick (Boophilus microplus) infestation on cattle, with particular reference to Bos indicus cattle and their crosses. Vet. Parasitol. 2006, 137, 1-10. [CrossRef]

12. Moges, N.; Hailemariam, T.; Fentahun, T.; Chanie, M.; Melaku, A. Bovine mastitis and associated risk factors in small holder lactating dairy farms in Hawassa, Southern Ethiopia. Glob. Vet. 2012, 9, 441-446. [CrossRef]

13. Rodrigues, D.S.; Leite, R.C. Economic impact of Rhipicephalus (Boophilus) microplus: Estimate of decreased milk production on a dairy farm. Arq. Bras. Med. Vet. Zootec. 2013, 65, 1570-1572. [CrossRef]

14. Heath, A.C.G.; Pearce, D.M.; Tenquist, J.D.; Cole, D.J.W. Some effects of a tick infestation (Haemaphysalis longicornis) on sheep. J. Agric. Res. 1977, 20, 19-22. [CrossRef]

15. Al-Hosary, A.A.T.; Ellah, M.R.A.; Ahmed, L.S.E.D. Evaluation of Oxidative Stress in Sheep Infested with Ticks and Concurrent Diagnosis of Theileriosis. Asian J. Anim. Vet. Adv. 2018, 13, 263-268. [CrossRef]

16. Ghafar, A.; Abbas, T.; Rehman, A.; Sandhu, Z.U.D.; Cabezas-Cruz, A.; Jabbar, A. Systematic review of ticks and tick-borne pathogens of small ruminants in Pakistan. Pathogens 2020, 9, 937. [CrossRef] [PubMed]

17. Perveen, N.; Muzafar, S.B.; Al-Deeb, M.A. Ticks and tick-borne diseases of livestock in the Middle East and North Africa: A review. Insects 2021, 12, 83. [CrossRef] [PubMed]

18. Sanhokwe, M.; Mupangwa, J.; Masika, P.J.; Maphosa, V.; Muchenje, V. Medicinal plants used to control internal and external parasites in goats. Onderstepoort J. Vet. Res. 2016, 83, 1-7. [CrossRef]

19. Soundararajan, C.; Nagarajan, K.; Muthukrishnan, S.; Prakash, M.A. Tick infestation on sheep, goat, horse and wild hare in Tamil Nadu. J. Parasit Dis. 2018, 42, 127-129. [CrossRef]

20. Soundararajan, C.; Latha, B.R.; Pandian, A. Prevalence of tick infestation in goats under different system of management. Int. J. Agric. Sci. Vet. Med. 2014, 2, 4-9.

21. Dimanopoulou, A.P.; Starras, A.G.; Diakou, A.; Lefkaditis, M.; Giadinis, N.D. Prevalence of tick species in sheep and goat flocks in areas of southern Greece. J. Hell. Vet. Med. Soc. 2017, 68, 205-210. [CrossRef]

22. Matei, I.A.; Ionică, A.M.; Corduneanu, A.; Domşa, C.; Sándor, A.D. The presence of ticks collected from ungulates in continental Eastern Europe. J. Vet. Res. 2021, 65, 71-275. [CrossRef]

23. Alessandra, T.; Santo, C. Tick-borne diseases in sheep and goats: Clinical and diagnostic aspects. Small Rumin. Res. 2012, 106, 6-11. [CrossRef]

24. Yin, H.; Luo, J. Ticks of small ruminants in China. Parasitol. Res. 2007, 101, 187-189. [CrossRef] [PubMed]

25. Eurostat. Goats Population—Annual Data. Available online: http://appsso.eurostat.ec.europa.eu/nui/show.do?dataset=apro_ mt_lsgoat\&lang=en (accessed on 12 April 2020).

26. Gelasakis, A.I.; Rose, G.; Giannakou, R.; Valergakis, G.E.; Theodoridis, A.; Fortomaris, P.; Arsenos, G. Typology and characteristics of dairy goat production systems in Greece. Livest. Sci. 2017, 197, 22-29. [CrossRef]

27. Papazahariadou, M.G.; Papadopoulos, E.G.; Himonas, C.A. Seasonal activity of ixodid ticks on goats in northern Greece. Vet. Rec. 1995, 136, 586-588.

28. Pavlidou, V.; Gerou, S.; Kahrimanidou, M.; Papa, A. Ticks infesting domestic animals in Northern Greece. Exp. Appl. Acarol. 2008, 45, 195-198. [CrossRef]

29. Chaligiannis, I.; Papa, A.; Sotiraki, S. Ticks feeding on ruminants and humans in Greece. Parasites Vectors 2014, 7, 1. [CrossRef]

30. Chaligiannis, I.; Musella, V.; Rinaldi, L.; Cringoli, G.; de la Fuente, J.; Papa, A.; Sotiraki, S. Species diversity and spatial distribution of ixodid ticks on small ruminants in Greece. Parasitol. Res. 2016, 115, 4673-4680. [CrossRef]

31. European Commission. Commission Implementing Regulation 2016/885 of 3 June 2016. Amending Regulation (EU) No 37/2010 as Regards the Substance “Eprinomectin" (Text with EEA Relevance). OJ L 148. 2016, pp. 1-3. Available online: http:/ / data.europa.eu/eli/reg_impl/2016/885/oj (accessed on 1 March 2021).

32. Rostang, A.; Devos, J.; Chartier, C. Review of the Eprinomectin effective doses required for dairy goats: Where do we go from here? Vet. Parasitol. 2020, 277, 108992. [CrossRef]

33. Papadopoulos, B.; Morel, P.C.; Aeschlimann, A. Ticks of domestic animals in the Macedonia region of Greece. Vet. Parasitol. 1996, 63, 25-40. [CrossRef]

34. Gelasakis, A.I.; Angelidis, A.S.; Giannakou, R.; Filioussis, G.; Kalamaki, M.S.; Arsenos, G. Bacterial subclinical mastitis and its effect on milk yield in low-input dairy goat herds. J. Dairy Sci. 2016, 99, 3698-3708. [CrossRef]

35. Gelasakis, A.I.; Angelidis, A.; Giannakou, R.; Arsenos, G. Bacterial subclinical mastitis and its effect on milk quality traits in low-input dairy goat herds. Vet. Rec. 2018, 183, 449. [CrossRef]

36. International Committee for Animal Recording. ICAR Recording Guidelines. International Agreement of Recording Practices. Available online: http:/ / www.icar.org/wp-content/uploads/2016/Guidelines-Edition-2016.pdf/ (accessed on 7 June 2018).

37. R Core Team. R: A Language and Environment for Statistical Computing; R Core Team: Vienna, Austria, 2021. Available online: https:/ / www.R-project.org/ (accessed on 30 December 2021). 
38. Estrada-Peña, A.; Mihalca, A.D.; Petney, T.N. Ticks of Europe and North Africa: A Guide to Species Identification; Springer: New York, NY, USA, 2017; pp. 75-404.

39. Norval, R.A.I.; Sutherst, R.W.; Jorgensen, O.G.; Kerr, J.D. The effects of the bont tick Amblyomma hebraeum, on milk production of Sanga and Sanga $\times$ Brahman cattle. Med. Vet. Entomol. 1997, 11, 143-147. [CrossRef] [PubMed]

40. Iqbal, A.; Siddique, F.; Mahmood, M.S.; Shamim, A.; Zafar, T.; Rasheed, I.; Saleem, I.; Ahmad, W. Prevalence and impact of ectoparasitic fauna infesting goats (Capra hircus) of district Toba Tek Singh, Punjab, Pakistan. Glob. Vet. 2014, 12, 158-164. [CrossRef]

41. White, E.C.; Hinckley, L.S. Prevalence of mastitis pathogens in goat milk. Small Rumin. Res. 1999, 33, 117-121. [CrossRef]

42. Al-Rubaie, M.A. Isolation and Characterization of Klebsiella spp. and Staphylococcus aureus from Engorged Adult Females of Rhipicephalus spp. J. Pure Appl. Microbiol. 2019, 13, 1763-1767. [CrossRef]

43. Andreotti, R.; de León, A.A.P.; Dowd, S.E.; Guerrero, F.D.; Bendele, K.G.; Scoles, G.A. Assessment of bacterial diversity in the cattle tick Rhipicephalus (Boophilus) microplus through tag-encoded pyrosequencing. BMC Microbiol. 2011, 11, 6. [CrossRef] [PubMed]

44. Kirecci, E.; Wasan, M.S.; Metin, T.U.; Bawar, A.M.; Omer, A.N.; Rızgar, M.K. Isolation and identification of tick-borne bacterial pathogens in Turkey and Iraq. Afr. J. Microbiol. Res. 2015, 9, 1608-1612. [CrossRef]

45. Bergonier, D.; de Crémoux, R.; Rupp, R.; Lagriffoul, G.; Berthelot, X. Mastitis of dairy small ruminants. Vet. Res. 2003, 34, 689-716. [CrossRef]

46. Koop, G.; van Werven, T.; Schuiling, H.J.; Nielen, M. The effect of subclinical mastitis on milk yield in dairy goats. J. Dairy Sci. 2010, 93, 5809-5817. [CrossRef]

47. Gray, J.S.; Dautel, H.; Estrada-Peña, A.; Kahl, O.; Lindgren, E. Effects of climate change on ticks and tick-borne diseases in Europe. Interdiscip. Perspect. Infect. Dis. 2009, 2009, 593232. [CrossRef]

48. Dantas-Torres, F.; Chomel, B.B.; Otranto, D. Ticks and tick-borne diseases: A One Health perspective. Trends Parasitol. 2012, 28, 437-446. [CrossRef] 